\title{
DIFFUSE INTERSTITIAL PULMONARY FIBROSIS AND RHEUMATOID ARTHRITIS
}

\author{
BY \\ W. C. WALKER, ${ }^{1}$ AND V. WRIGHT ${ }^{2}$ \\ From the Rheumatism Research Unit, University Department of Medicine, General Infirmary at Leeds, \\ and the Royal Bath Hospital, Harrogate
}

Diffuse interstitial pulmonary fibrosis in rheumatoid arthritis has received considerable attention since it was first described 20 years ago (Ellman and Ball, 1948). It appears that few authorities now doubt that the association is valid, despite the absence of statistical evidence from controlled investigations (Aronoff, Bywaters, and Fearnley, 1955; Talbott and Calkins, 1964; Stack and Grant, 1965). Locke (1963), in a radiographic study, did find an incidence of 28 per cent. compared with none in a control group, but this was a highly selected series of patients. Curiously, more support for the concept has arisen from uncontrolled observations such as those of Cruickshank (1959), Brannan, Goode, Divertie, and Baggenstoss (1964), Patterson, Harville, and Pierce (1965), and Thompson (1965), where a frequency varying from $1 \cdot 1$ to 5 per cent. has been found. The high incidence of rheumatoid factor in the sera of patients with interstitial pulmonary fibrosis even in the absence of rheumatoid arthritis (Turner-Warwick and Doniach, 1965) has further suggested a link between the two diseases. However, Scadding (1960) and Stack, Grant, Irvine, and Moffat (1965) did not find rheumatoid factor in their series. Whether the pulmonary lesions are a true systemic manifestation of rheumatoid arthritis or related in some other way is not yet known.

As was recently stressed much controversy still surrounds the subject (Leading Article, 1967). The purpose of the investigation to be described was to re-examine the problem by studying a large series of unselected patients with rheumatoid arthritis and comparing them with a similar series with degenerative joint disease as a control group.

\section{Material and Methods}

516 patients with classical or definite rheumatoid arthritis (RA) were studied. The series comprised new and follow-up cases attending a rheumatism clinic over

(1)Consultant physician, Wakefield Hospitals.

(2)Senior lecturer, Consultant physician in Rheumatology. an 18-month period. Also included were direct admissions to hospital for treatment of RA during the same period. A control group of 301 patients with degenera- $\omega$ tive joint disease (DJD), primary and secondary osteo- N arthrosis, and disc degeneration, were collected in the $N$ same manner as rheumatoid patients. Four additional 음 patients with interstitial pulmonary fibrosis (IPF) and RA were specially referred by other physicians and were not included in the analysis except where indicated.

In each case a full clinical examination was made. Functional capacity was assessed and graded (Empire Rheumatism Council, 1960). The extent of the arthritis was classified by the number of joints involved in the upper and lower limbs, taking no account of small joint involvement: mild 1 or 2 , moderate 3 or 4 , severe more than 4. Joint involvement was accepted in the presence of deformity, or two of the following: swelling, tenderness, limitation of movement. Occupational and smoking histories were recorded. A full blood count and erythrocyte sedimentation rate (ESR) were performed on each patient. The Waaler-Rose differential agglutination of sensitized sheep cells (SCAT) was done on all patients using the technique of Greenbury (1957); L.E.cells were sought in 248 patients and serum proteins were estimated in 212.

All patients had an $x$-ray examination of the chest, which was read by one of us (W.C.W.) without knowledge of the group to which they belonged. All rheumatoid subjects had films taken of their hands and feet, and the control group had films taken of the major joints involved. Rheumatoid changes of the hands and feet were graded as follows:

(1) Severe

Four or more major erosions

or deformity and at least two major erosions or bony ankylosis

(2) Moderate

Two or three major erosions

or one major erosion and deformity.

(3) Mild

one major erosion

or unequivocal minor erosions.

(4) Doubtful

Juxta-articular rarefaction only. 
The following tests of lung function were employed in selected patients:

(1) Minute Volume (MV).-This was measured with a Wright's vane anemometer.

(2) Lung Volumes.-The residual volume was determined by the closed circuit helium dilution method (Gilson and Hugh-Jones, 1949). A Godart "Pulmotest" was used for this determination, as well as for the other lung volume measurements.

(3) Forced Expiratory Volume in one second $\left(\mathrm{FEV}_{1}\right)$. This was estimated using the Godart "Pulmotest".

(4) Gas Transfer.-This was measured by the carbon monoxide uptake test, using the single-breath method by the technique described by Ogilvie, Forster, Blakemore, and Morton (1957).

(5) Blood Gas Studies.-The arterial carbon dioxide tension was estimated by the re-breathing method of Campbell and Howell (1960) in the majority of cases. In a few blood was taken by needle puncture from the femoral artery and the oxygen tension was measured using a Beckman oxygen electrode. When arterial blood was taken the carbon dioxide tension was measured with the Astrup micro-electrode (Astrup, Jørgensen, Siggaard Andersen, and Engel, 1960).

When expressed as a percentage of normal the data used were those of Needham, Rogan, and McDonald (1954) as modified by Comroe, Forster, DuBois, Briscoe, and Carlsen (1962). Predicted normal values for gas transfer were obtained from the formulae of Ogilvie and others (1957).

\section{Features of Rheumatoid and Control Groups}

Of the 516 patients with RA, 376 (73 per cent.) were women and of the control group 239 (79 per cent.). The age distribution was similar in the two groups (Table I).

Subcutaneous nodules were present in 44 per cent. of the men and in 25 per cent. of the women. Ocular lesions were present in twenty patients (seventeen of whom were women), splenomegaly in seventeen, neuropathy in eight, and myopathy in six.

\section{Results}

Diffuse IPF was accepted as present when there were radiographic appearances and physiological changes consistent with this diagnosis and when no evidence of an alternative pathology was found on investigation. Eight (1.6 per cent.) of the patients with RA, but none of those with DJD, had IPF. Of the total twelve patients with IPF, nine were men. All the patients were in the 6th or 7 th decade at the time of examination, the mean age being 61 years (range 54 to 67 ). The lung disease preceded the arthritis in one patient and in three it was present within 2 years.

\section{Respiratory Features}

Eight of the total series of twelve patients had a cough, usually with scanty mucoid sputum. One patient experienced dyspnoea at rest, two on slight exertion, and five on moderate exertion; in four there was no dyspnoea but three of these had severe restriction of activities due to RA. Haemoptysis occurred in two patients and chest pain in one. All except three patients had clubbing, which was gross in four, moderate in two, and slight in three. Crepitations, usually at the lung bases, were heard in all but two patients.

The shortest duration of symptoms was 5 weeks, but a chest $x$ ray 18 months previously contained well-marked changes. At the other extreme a chest $x$ ray taken 10 years previously was reported as showing basal fibrosis (the film was not available for personal review) and at that time finger clubbing was recorded. In the remaining patients the duration was dated from the onset of symptoms attributable to IPF or from the date of an abnormal $x$ ray, if symptoms at that time were not present. The mean duration was $4 \cdot 7$ years. In the four patients without a history of breathlessness the lung disease had been present for at least 4 years.

One patient received corticosteroids for his lung condition, because of rapidly increasing dyspnoea. It appeared that the downhill course was halted. In two patients hydroxychloroquine was given for the

TABLE I

AGE AND SEX DISTRIBUTION (PERCENTAGES IN PARENTHESIS)

\begin{tabular}{c|c|c|c|c|c|c|c|}
\hline \multirow{2}{*}{ Sex } & \multirow{2}{*}{ Diagnosis } & \multicolumn{5}{|c|}{ Age at Onset (yrs) } \\
\cline { 2 - 7 } & & $<30$ & $30-39$ & $40-49$ & $50-59$ & $60-69$ & $70+$ \\
\hline Male & RA & $3(2)$ & $10(7)$ & $26(19)$ & $55(39)$ & $42(30)$ & 4 \\
& DJD & $1(2)$ & $8(13)$ & $11(18)$ & $14(23)$ & $20(32)$ & $8(13)$ \\
\hline Female & RA & $7(2)$ & $29(8)$ & $66(18)$ & $128(34)$ & $111(30)$ & $35(9)$ \\
& DJD & $7(3)$ & $14(6)$ & $18(8)$ & $67(28)$ & $75(31)$ & $58(24)$ \\
\hline
\end{tabular}


lung disease. One died after $3 \frac{1}{2}$ months from coronary thrombosis and in the second the vital capacity and gas transfer increased slightly after 3 months treatment. However $1 \frac{1}{2}$ months later the vital capacity had fallen below the pre-treatment figure and the gas transfer had also fallen.

\section{Smoking History}

Two of the female patients in the group were non-smokers. The remaining patients had all smoked for more than 20 years. One woman and three men smoked from 1 to 10 cigarettes daily, two men smoked from 11 to 20 daily, and four men smoked more than twenty daily. In the rheumatoid population 60 per cent. of the women were nonsmokers. Of the men in the total rheumatoid population, 21 per cent. had smoked 1 to 10 cigarettes daily for more than 20 years compared with 33 per cent. in the group with IPF; 33 per cent. had smoked 11 to 20 cigarettes daily for more than 20 years compared with 22 per cent., and 14 per cent. had smoked more than twenty cigarettes daily for more than 20 years compared with 44 per cent.

\section{Occupational History}

There was no evidence that occupational factors had been operative in the production of IPF. Five were office workers, two worked in engineering, two in the woollen industry, one was a driver, one a highways superintendent, and one a railway signalman.

\section{Arthritic Features}

Only one patient in the group with IPF developed arthritis before the age of $\mathbf{4 6}$ years, compared with 52 per cent. of the rheumatoid population. The mean age at onset of arthritis was 54 years (range 41 to 61 ).

There were six patients in functional Grade 2, five in Grade 3, and one in Grade 5, a distribution similar to that in the rheumatoid population. The extent of the arthritis in those with lung disease was essentially the same as in the rheumatoid population. The percentages of mild, moderate, and severe were 25,33 , and 42 compared with 25,24 , and 52 respectively.

Nine of the twelve patients with lung disease had subcutaneous nodules ( 7 men and 2 women). This was a higher incidence than in the rheumatoid population, in which 44 per cent. of the men and 25 per cent. of the women had subcutaneous nodules.
The only other definite example of systemic manifestations of rheumatoid arthritis in the series with lung disease was one man with pericarditis.

\section{Chest Radiography}

The changes in the chest radiographs were bilateral in all patients and symmetrical in nine. Both lungs were evenly involved in eight and in the remainder the mid and/or lower zones were predominantly affected. The radiographic abnormality consisted of fine mottling in three patients, coarse mottling in four (with cystic change in one), and a reticular pattern in the remaining five. One patient had pleural thickening and a second had a small effusion.

Particular attention was paid to the lung markings. Prominent lung markings were present with equal frequency in rheumatoid and control patients, and in those who were further investigated there was no definite evidence of IPF.

\section{Lung Function Tests}

The results of selected tests of lung functions in nine of the rheumatoid patients are shown in Table II (opposite).

Only one had a vital capacity below the normal range. The gas transfer was significantly reduced in eight and in the other the figure was at the lower limit of normal, namely 70 per cent. In this case the arterial oxygen tension remained normal after exercise and, although the latter could not be strenuous because of his arthritis, it was sufficient to provoke definite dyspnoea. The diagnosis of IPF was subsequently confirmed by lung biopsy. These results show less lung restriction than usually encountered in cases with IPF. It should, however, be realized that all these cases were seen primarily because of their arthritis, and by way of contrast the results obtained in six cases with IPF, apparently idiopathic, are also shown in Table II.

The results are compared with the rheumatoid group in the Figure (opposite), where they are expressed as a percentage of predicted normal (the shaded areas on the scattergram representing the normal range).

The dominant complaint of the patients without RA was breathlessness. Lung restriction was much more marked in this group. Gas transfer was considerably impaired in four of the five cases in which this was tested. In the one in which the figure was within the normal range, arterial oxygen fell significantly on exercise. In the one patient in whom the test was not possible, because of a very reduced vital capacity, the arterial oxygen tension was considerably reduced at rest. 
TABLE II

LUNG FUNCTION TESTS IN NINE PATIENTS WITH RHEUMATOID IPF, AND SIX PATIENTS WITH IPF WITHOUT RA

\begin{tabular}{|c|c|c|c|c|c|c|}
\hline Diagnosis & Case No. & Sex & VC & TLC & FEV $_{1}$ & $\begin{array}{c}\mathrm{CO}_{2} \text { Uptake } \\
\text { (ml./min./mm. } \mathrm{Hg})\end{array}$ \\
\hline $\begin{array}{l}\text { Rheumatoid } \\
\text { IPF }\end{array}$ & $\begin{array}{l}1 \\
2 \\
3 \\
4 \\
5 \\
6 \\
7 \\
8 \\
9\end{array}$ & $\begin{array}{l}\mathbf{M} \\
\mathbf{F} \\
\mathbf{M} \\
\mathbf{M} \\
\mathbf{F} \\
\mathbf{M} \\
\mathbf{M} \\
\mathbf{M} \\
\mathbf{M}\end{array}$ & $\begin{array}{l}2 \cdot 98 \\
2 \cdot 04 \\
3 \cdot 44 \\
2 \cdot 94 \\
2 \cdot 44 \\
4 \cdot 3 \\
3 \cdot 73 \\
4 \cdot 48 \\
2 \cdot 83\end{array}$ & $\begin{array}{l}3 \cdot 8 \\
2 \cdot 98 \\
5 \cdot 11 \\
4 \cdot 58 \\
3 \cdot 1 \\
6 \cdot 55 \\
4 \cdot 97 \\
6 \cdot 4 \\
4 \cdot 44\end{array}$ & $\begin{array}{l}2 \cdot 4 \\
1 \cdot 85 \\
2 \cdot 72 \\
2 \cdot 19 \\
1.97 \\
2 \cdot 67 \\
2 \cdot 88 \\
2 \cdot 37 \\
2 \cdot 03\end{array}$ & $\begin{array}{r}14 \cdot 5(61) \\
10 \cdot 1(42) \\
10 \cdot 2(42) \\
18 \cdot 2(58) \\
7 \cdot 9(34) \\
14 \cdot 5(61) \\
13 \cdot 5(46) \\
13 \cdot 5(40) \\
17 \cdot 5(70)\end{array}$ \\
\hline $\begin{array}{l}\text { IPF } \\
\text { without } \\
\text { Rheumatoid } \\
\text { Arthritis }\end{array}$ & & $\begin{array}{l}\mathbf{F} \\
\mathbf{M} \\
\mathbf{M} \\
\mathbf{M} \\
\mathbf{F} \\
\mathbf{F}\end{array}$ & $\begin{array}{l}1 \cdot 31 \\
2 \cdot 67 \\
1 \cdot 71 \\
3 \cdot 33 \\
1 \cdot 0 \\
1 \cdot 99\end{array}$ & $\begin{array}{l}2 \cdot 29 \\
3 \cdot 32 \\
2 \cdot 22 \\
5 \cdot 4 \\
1 \cdot 67 \\
2 \cdot 8\end{array}$ & $\begin{array}{l}1 \cdot 09 \\
22 \cdot 4 \\
1 \cdot 36 \\
1 \cdot 53 \\
1 \cdot 5\end{array}$ & $\begin{array}{r}5.9(25) \\
14.5(50) \\
5.7(21) \\
10.8(37) \\
18.4(81) \dagger\end{array}$ \\
\hline
\end{tabular}

$\mathrm{VC}=$ Vital capacity (litres).

TLC = Total lung capacity (litres).

FEV $_{1}=$ Forced expiratory volume in 1 sec. (litres).

Figures in parenthesis are percentages of predicted normal values.

-Inadequate VC for test to be done. Arterial oxygen tension $=29 \mathrm{~mm}$. Hg at rest.

†Arterial oxygen tension at rest $=88 \mathrm{~mm}$. $\mathrm{Hg}$; after exercise $=45 \mathrm{~mm}$. $\mathrm{Hg}$.

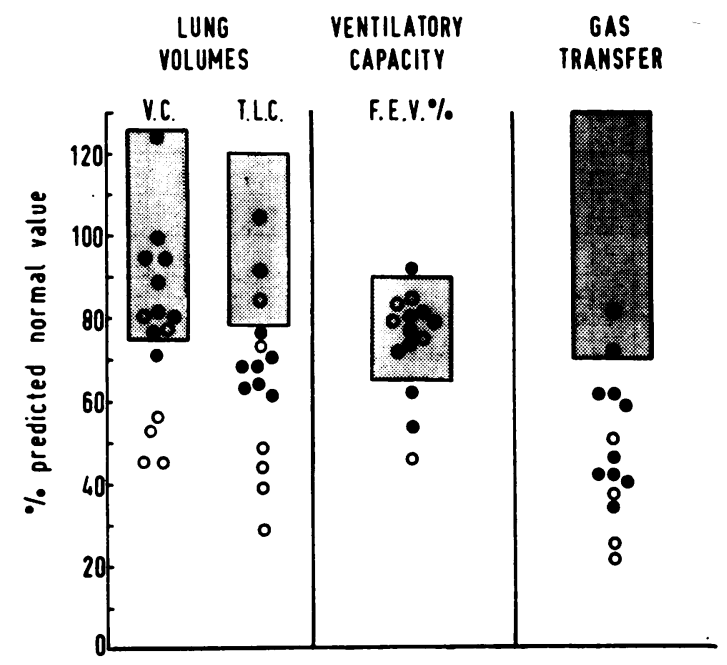

Figure.-Results of lung function tests in cases of rheumatoid arthritis with interstitial lung disease and in cases of interstitial lung disease without arthritis.

RA with IPF

IPF without RA

\section{Pathology}

Specimens for pathological examination were obtained from three patients, two by lung biopsy, and one at autopsy. Case 1 showed diffuse interstitial fibrosis with obliteration and gross distortion of alveolar spaces. Case 9 showed diffuse interstitial fibrosis and cellular infiltration, consisting mainly of lymphocytes, with some plasma cells. There were numerous distorted air passages filled with macrophages. The third patient (Case 9) showed diffuse fibrosis with partial obliteration of respiratory passages and thickening of residual alveolar walls.

\section{Laboratory Investigations}

Four of the patients had a haemoglobin level between 10.5 and $12.6 \mathrm{~g}$. per $100 \mathrm{ml}$., two of whom were women. The remainder had haemoglobin levels of over $12.6 \mathrm{~g}$. per $100 \mathrm{ml}$. There was no suggestion of an increased incidence of anaemia in those with lung disease. Nine (75 per cent.) of the twelve patients with lung disease had an ESR greater than $40 \mathrm{~mm}$./1st hr compared with 45 per cent. of the rheumatoid population.

Rheumatoid factor was present in the blood of eleven of the twelve patients with lung disease. Two had a positive latex slide test. In the remaining nine patients the SCAT was positive in a reciprocal titre of 32 in 1, 512 or greater in five, and 128 or 256 in the remaining three.

Two patients, both with nodular rheumatoid arthritis, had L.E.-cells in the peripheral blood. They were absent from the remaining ten.

In the group with lung disease, three had a decreased serum albumin, and five an increased serum globulin amongst the ten examined. This compared with an incidence of 19 and 26 per cent. respectively in the rheumatoid population. Eight (80 per cent.) of the ten in whom electrophoresis was performed had an abnormal pattern, compared with 68 per cent. of those in the rheumatoid population. The changes observed were essentially those seen in uncomplicated RA, namely an increase in 
the gamma and alpha $a_{2}$ globulins, and less commonly a decreased albumin and increased alpha $a_{1}$ and beta globulins.

\section{Joint Radiographs}

Comparison between the severity of changes in the hands and feet is shown in Table III. There was no significant difference. The duration of arthritis in the men was almost exactly comparable with that of the RA population as a whole.

\section{Discussion}

\section{Terminology}

In this paper we have used the term "diffuse interstitial pulmonary fibrosis" to describe the syndrome resulting from progressive fibrosis of the interstitial tissue of the lungs, not due to a recognizable cause. Scadding (1964) argues persuasively for the term "fibrosing alveolitis" for the same pathological process, while Stack and others (1965) favour "diffuse interstitial lung disease". We chose the older term since it still appears to be that most widely employed.

\section{Validity of Association}

In this investigation 1.6 per cent. of the patients with RA had IPF compared with none in the control group, a difference which is not statistically significant. Nevertheless, this incidence is similar to that of Patterson and others (1965) and Thompson (1965). The frequence of IPF in the general population is not known but it is certainly rare, and it is difficult to believe that the consistent detection of these patients in different rheumatoid populations is without significance. Moreover, in respiratory units, one-eighth of patients with IPF have RA (Thompson, 1965).

Cruickshank $(1957,1959)$ found interstitial pneumonia in five of 100 autopsies on rheumatoid subjects, whereas none was found in 200 autopsies on subjects with ankylosing spondylitis. This differ- ence was significant $\left(\chi^{2}=7 \cdot 35 ; P<0.01\right)$, and significantly different from the figures of Mallory (1948) who found sixteen examples in 6,000 unselected autopsies $\left(\chi^{2}=51 \cdot 18 ; \mathrm{P}<0.001\right)$. Rheumatoid granulomata were present in the lungs of 10 per cent. of RA patients with IPF in the literature (Walker, 1966).

Locke (1963) thought that IPF was more frequent than the above figures suggest and concluded from his controlled study that it was the commonest respiratory complication of rheumatoid arthritis. He diagnosed the condition from the chest radiographs and included as one diagnostic criterion an exaggeration of the peripheral vascular pattern of the lungs. The incidence he found was considerably in excess of any other series, namely 28 per cent. He did not, however, present full clinical and physiological data on all the cases cited. In this study we found prominent lung markings with equal frequency in the rheumatoid and control groups.

\section{Rheumatoid Features}

The increased prevalence of IPF among older men noted in the literature and confirmed in this series is striking despite the fact that RA is commoner in women. A point apparent in this study, not previously stressed, is the tendency for IPF to occur in patients whose arthritis begins late.

Analysis of the literature had suggested a greater frequency of subcutaneous nodules in men but not in women with IPF (Walker and Wright, 1968). However, this series and that of Patterson and others (1965) strongly suggest that there is an association in both sexes. It has been suggested that there is a correlation between rheumatoid arthritis, constrictive pericarditis, and IPF (Leading Article, 1968), but we could find no evidence to support this.

\section{Respiratory Features}

It is of interest to note the relative lack of respiratory disability both clinically and physiologically in the rheumatoid patients with IPF in this series.

TABLE III SEVERITY OF $X$-RAY CHANGES IN HANDS AND FEET OF IPF AND RA POPULATION

\begin{tabular}{|c|c|c|c|c|c|c|c|}
\hline \multirow{2}{*}{$X$ rays } & \multirow{2}{*}{ Diagnosis } & \multirow{2}{*}{ No. } & \multicolumn{5}{|c|}{$X$-ray Changes } \\
\hline & & & Normal & Doubtful & Mild & Moderate & Severe \\
\hline Hands & $\begin{array}{l}\text { IPF } \\
\text { RA }\end{array}$ & 503 & $39(10)$ & $\begin{array}{r}2(20) \\
48(10) \\
\end{array}$ & $\begin{array}{r}2(20) \\
103(20) \\
\end{array}$ & $\overline{70}(14)$ & $\begin{array}{r}5(50) \\
243(48) \\
\end{array}$ \\
\hline Feet & $\underset{\text { RA }}{\text { IPF }}$ & $\begin{array}{r}9 \\
486\end{array}$ & $52(22)$ & $32 \stackrel{11}{(7)}$ & $\begin{array}{r}3(33) \\
121(25)\end{array}$ & $\begin{array}{l}1(11) \\
97(20)\end{array}$ & $\begin{array}{r}2(22) \\
184(38)\end{array}$ \\
\hline
\end{tabular}


This was considerably less than in the small series of patients studied without RA, as well as the large series of similar patients described by others (Scadding, 1960; Livingstone, Lewis, Reid, and Jefferson, 1964; Stack and others, 1965). All other clinical and radiographic features were similar, except that pleural abnormalities were present in two of our patients and in 17 per cent. of those reported in the literature (Walker and Wright, 1968).

It must be borne in mind that eight of the patients were detected during a survey of a rheumatoid population, and it is possible that those with prominent respiratory disability were referred elsewhere. However, the four referred by other physicians were no more disabled than the remainder. This suggests that the degree of respiratory disability may be less and the prognosis better than in the those without RA. Our patients were mainly middle-aged or elderly men, and Stack and others (1965), in a review of 42 patients with IPF, speculated that there may be a benign condition in older subjects where the $x$-ray appearances are similar without corresponding symptoms or impairment of respiratory function.

Two of the eight patients reported by Stack and Grant (1965) developed malignant pulmonary tumours, and these have been reported by others (Aronoff and others, 1955; Cruickshank, 1959; Lee and Brain, 1962; Thompson and Leathart, 1965). We have not yet observed this in any of our patients.

\section{Treatment}

Corticosteroid therapy was given to one of our patients as treatment for his lung disease with slight but temporary benefit. Although a favourable response has been recorded in some cases, this has rarely been prolonged, and indeed Stack and Grant (1965) felt that in two of their patients the drug may have hastened the progression of the disease. Patterson and others (1965) did not find that any treatment influenced the progress of the lung disease. We employed hydroxychloroquine in two patients and in one there may have been slight but temporary benefit.

\section{Pathogenesis}

The precise reason why some patients have RA and IPF is unknown. IPF is certainly more common in those with high titres of SCAT, and Tomasi, Fudenberg, and Finby (1962) suggested that the precipitation of rheumatoid factor in the pulmonary capillaries might be the explanation of the lung changes. Since not all patients have a strongly positive SCAT (sometimes it is negative) and there is no universal histological evidence of primary vascular involvement, this explanation seems unlikely.

Turner-Warwick and Doniach (1965) reported the results of auto-antibody studies in 48 patients with IPF, fourteen of whom had RA. These workers noted a discrepancy between the slide latex F II test and the SCAT, similar to that previously noted in Caplan's syndrome (Caplan, Payne, and Withey, 1962). Occupational factors are, of course, of aetiological importance in Caplan's syndrome. Our data were in agreement with the view of Thompson and Leathart (1965) that occupation did not produce the lung disease, but the sex and age incidence, and the smoking habits raise the possibility that environmental factors may be in some way operative in the production of IPF in patients with the rheumatoid diathesis.

\section{Summary}

A clinical, radiographic, and serological study of 516 patients with rheumatoid arthritis and 301 with degenerative joint disease has been undertaken to re-evaluate the significance of diffuse interstitial pulmonary fibrosis in rheumatoid arthritis. Eight ( 1.6 per cent.) of the rheumatoid patients had such lung lesions, and a further four were specially referred; nine of the twelve were men. None of the control group showed the condition.

The pulmonary disease was more benign clinically and physiologically than interstitial pulmonary fibrosis without rheumatoid arthritis. Otherwise the clinical, radiological, and pathological features were similar, apart from the presence of pleural changes in two patients. There was no evidence that occupational factors played a role in the aetiology, but prolonged heavy smoking was more common than in the rheumatoid population. Although there was some benefit from corticosteroids in one patient and from hydroxychloroquine in one of two patients so treated, the effect was transient.

Rheumatoid arthritis was of late onset in those with interstitial pulmonary fibrosis, and subcutaneous nodules occurred more frequently. Otherwise there was no difference clinically or radiographically. Haemoglobin levels were similar to those of the control rheumatoid population, but the ESR was higher, eleven had rheumatoid factor in the serum and protein abnormalities were more frequent.

We are grateful to Drs M. R. Jeffrey, J. R. Fountain, and T. G. Reah for referring patients. 


\section{REFERENCES}

Aronoff, A., Bywaters, E. G. L., and Fearnley, G. R. (1955). Brit. med. J., 2, 228 (Lung lesions in rheumatoid arthritis).

Astrup, P., Jørgensen, K., Siggard Andersen, O., and Engel, K. (1960). Lancet, 1, 1035 (The acidbase metabolism: a new approach).

Brannan, H. M., Good, C. A., Divertie, M. B., and Baggenstoss, A. H. (1964). J. Amer. med. Ass., 189, 914 (Pulmonary disease associated with rheumatoid arthritis).

Campbell, E. J. M., and Howell, J. B. L. (1960). Brit. med. J., 1, 1209 (Blood carbon-dioxide tension).

Caplan, A., Payne, R. B., and Withey, J. L. (1962). Thorax, 17, 205 (A broader concept of Caplan's syndrome related to rheumatoid factors).

Comroe, J. H., Forster, R. E., DuBois, A. B., Briscoe, W. A., and Carlsen, E. (1962). In "The Lung", 2nd ed., p. 325. Year Book Medical Publishers, Chicago.

Cruickshank, B. (1957). Proc. roy. Soc. Med., 50, 462 (Rheumatoid arthritis and rheumatoid disease).

- (1959). Brit. J. Dis. Chest, 53, 226 (Interstitial pneumonia and its consequences in rheumatoid disease).

Ellman, P., and Ball, R. E. (1948). Brit. med. J., 2, 816 ("Rheumatoid disease" with joint and pulmonary manifestations).

Empire Rheumatism Council (1960). Ann. rheum. Dis., 19, 95 (Gold therapy in rheumatoid arthritis. Report of a multi-centre controlled trial).

Gilson, J. C., and Hugh-Jones, P. (1949). Clin. Sci., 7, 185 (The measurement of the total lung volume and breathing capacity).

Greenbury, C. L. (1957). "The Rose-Waaler Test". Association of Clinical Pathologists Broadsheet No. 18.

Leading Article (1967). Brit. med. J., 1, 186 (Rheumatoid lungs and rheumatoid piles).

- (1968). Ibid., 1, 265 (Non-tuberculous constrictive pericarditis).

Lee, F. I., and Brain, A. T. (1962). Lancet, 2, 693 (Chronic diffuse interstitial pulmonary fibrosis and rheumatoid arthritis).

Livingstone, J. L., Lewis, J. G., Reid, L., and Jefferson, K. E. (1964). Quart. J. med., 33, 71 (Diffuse interstitial pulmonary fibrosis).

Locke, G. B. (1963). Clin. Radiol., 14, 43 (Rheumatoid lung).

Mallory, T. B. (1948). Radiology, 51, 468 (Pathology of pulmonary fibrosis, including chronic pulmonary sarcoidosis).

Needham, C. D., Rogan, M. C., and McDonald, I. (1954). Thorax, 9, 313 (Normal standards for lung volumes, intrapulmonary gas-mixing, and maximum breathing capacity).

Ogilvie, C. M., Forster, R. E., Blakemore, W. S., and Morton, J. W. (1957). J. clin. Invest., 36, 1 (A standardized breath-holding technique for the clinical measurement of the diffusing capacity of the lung for carbon monoxide).

Patterson, C. D., Harville, W. E., and Pierce, J. A. (1965). Ann. intern. Med., 62, 685 (Rheumatoid lung disease).

Scadding, J. G. (1960). Brit. med. J., 1, 443 (Chronic diffuse interstitial fibrosis of the lungs).

- (1964). Ibid., 2, 686 (Letter: Fibrosing alveolitis).

Stack, B. H. R., and Grant, I. W. B. (1965). Brit. J. Dis. Chest, 59, 202 (Rheumatoid interstitial lung disease).

—, , Irvine, W. J., and Moffat, M. A. J. (1965). Amer. Rev. resp. Dis., 92, 939 (Idiopathic diffuse interstitial lung disease).

Talbott, J. A., and Calkins, E. (1964). J. Amer. med. Ass., 189, 911 (Pulmonary involvement in rheumatoid arthritis).

Thompson, M. (1965). In "Progress in Clinical Rheumatology", ed. A. St. J. Dixon, pp. 10-26. Churchill, London.

- and Leathart, G. L. (1965). Ann. rheum. Dis., 24, 176 (Chronic diffuse pulmonary infiltration complicating rheumatoid arthritis). (Abstract.) 
Tomasi, T. B., Fudenberg, H. H., and Finby, N. (1962). Amer. med. J., 33, 243 (Possible relationship of rheumatoid factors and pulmonary diseases).

Turner-Warwick, M., and Doniach, D. (1965). Brit. med. J., 1, 886 (Auto-antibody studies in interstitial pulmonary fibrosis).

Walker, W. C. (1966). “The Lungs in Rheumatoid Arthritis". M.D. Thesis, University of Edinburgh.

— and Wright, V. (1968). Medicine (Baltimore), 47, 501 (Pulmonary lesions and rheumatoid arthritis).

La fibrose pulmonaire interstitielle diffuse et la polyarthrite rhumatoide

\section{RÉSUMÉ}

Une étude clinique, sérologique et radiographique de 516 malades atteints de polyarthrite rhumatoïde et 301 atteints de dégénérescence des articulations a été entreprise afin de réévaluer la signification de la fibrose pulmonaire interstitielle diffuse dans la polyarthrite rhumatoïde. Huit (1,6 pour cent) des malades rhumatoïdes avaient de telles lésions pulmonaires, et quatre autres avaient été spécialement inclus; neuf des douze étaient des hommes. Aucun du groupe de témoins montrait cette lésion.

La maladie pulmonaire était plus bénigne cliniquement et physiologiquement que la fibrose pulmonaire interstitielle sans la polyarthrite rhumatoïde. Autrement les signes cliniques, radiologiques et pathologiques étaient semblables, à part la présence des changements pleuraux chez deux malades. Il n'y avait aucune preuve que les facteurs professionels jouaient un rôle dans l'étiologie, mais de grands fumeurs étaient plus frequents que chez les rhumatoïdes. L'effet du traitement par les corticostéroïdes chez un malade et par l'hydroxychloroquine chez un autre n'était que transitoire.

L'arthrite rhumatoïde avait commencé tard chez ceux atteints de fibrose pulmonaire interstitielle, et les nodules sous-cutanés étaient vus plus souvent. Autrement, il n'y avait aucune différence cliniquement ou radiographiquement. Les taux d'hémoglobine étaient semblables à ceux des témoins rhumatoïdes, mais la vitesse de sédimentation globulaire était plus élévé. Onze d'entre eux avaient le facteur rhumatoïde dans le sérum, et les anomalies des protéines étaient plus fréquentes.

\section{Fibrosis pulmonar intersticial difusa y poliartritis reumatoide}

\section{Sumario}

Se ha emprendido un estudio clínico, radiológico y serológico de 516 pacientes con poliartritis reumatoide y 301 con enfermedad articular degenerativa, para revalorar el significado de la fibrosis pulmonar intersticial difusa en la poliartritis reumatoide. Ocho (1,6 por ciento) de los pacientes reumáticos tenían esas lesiones pulmonares, y otros cuatro fueron especialmente añadidos; neuve de los doce eran hombres. Ninguno del grupo testigo mostró la condición. La enfermedad pulmonar fue, clínica y fisiológicamente, más benigna que la fibrosis pulmonar intersticial sin poliartritis reumatoide. De otro modo, las características clínicas, radiologicas y patológicas eran similares, aparte de la presencia de cambios pleurales en dos pacientes. No hubo pruebas de que los factores ocupacionales desempeñaran un papel en la etiología, pero el hábito prolongado de fumar intensamente era más común que en los pacientes reumáticos. Si bien se notaron ciertos beneficios derivados de los corticosteroides en un paciente y de la hidroxicloroquina en uno o dos pacientes así tratados, el efecto fue transitorio.

La poliartritis reumatoide era de desarrollo tardío en aquellos con fibrosis pulmonar intersticial, y los nódulos subcutáneos occurían más frecuentemente. De otro modo, no hubo diferencia clínica o radiográficamente. Los niveles hemoglobínicos eran similares a aquellos de los pacientes reumáticos testigo, pero la VSE era más alta, once tenían factor reumático en el suero y las anormalidades proteínicas eran más frecuentes. 